\title{
When Employers Betray: A Study of Psychological Contract Breach Among Croatian Employees*
}

\author{
Zvonimir Galic *** \\ Maša Tonković Grabovac \\ Irena Gotvald \\ Željko Jerneić
}

\begin{abstract}
In this paper we report the results of a study exploring psychological contract breach (PCB) in a heterogeneous sample of Croatian employees $(N=363)$. In addition to reporting PCB, the participants informed us about their basic demographic characteristics, job attitudes (job satisfaction and organizational commitment) and reported three aspects of their job performance (in-role performance, organizational citizenship behavior, counterproductive work behavior). Our analyses showed that PCB experience depended on participants' characteristics, and, more importantly, was negatively related to job attitudes and job performance. Thus, the detrimental effect of PCB reported in the organizational behavior literature was replicated among Croatian employees.
\end{abstract}

Keywords: organizational behavior; psychological contract; psychological contract breach; job attitudes; job performance

JEL Classification: M12, D23

\section{Introduction}

Organizational behavior researchers have convincingly claimed that mutual obligations between an employer and an employee are defined, in addition to a legal contract, with a psychological contract (Rousseau, 1990). Psychological contract con-

\footnotetext{
* Acknowledgment: This work has been supported in part by Croatian Science Foundation under the project 6719.

** Zvonimir Galić, Maša Tonković Grabovac, Irena Gotvald and Željko Jerneić are at University of Zagreb, Faculty of humanities and social sciences, Zagreb, Croatia.
} 
sists of employee's beliefs about explicit and implicit promises that were given to him/her in exchange for the time and effort (s)he invests in the organization. For example, for time and effort invested in job-related activities and achieved results, employees might expect appropriate compensation, permanent position, and continuous advancement possibilities. By the definition, psychological contract is subjective, resides in the "eye of the beholder", and stems from the employee's interpretation of events in the organization. Dominantly, it is created already in the recruitment phase, but can also be revised during a period of job change (e.g., due to a promotion or a lateral move in the organization), or as a result of organizational change interventions (Rousseau \& McClean Parks, 1993).

Psychological contract theory sees the relationship between an employee and his/ her employer as a social exchange of tangible and intangible resources, guided by the reciprocity norm (Gouldner, 1960). Therefore, the theory has its roots in social exchange theory (Levinson, 1965; Cropanzano \& Mitchell, 2005) that differentiates social from economic exchanges. While an economic exchange entails two sides that have a formal contract with highly specified obligations and defined timeframe for the exchange, a social exchange understands unspecified obligations where one side must believe the other side that received favors will be returned. The returned favors strengthen the mutual trust and facilitate future interactions.

Psychological contract has been shown as a useful framework for understanding the employment relationship and predicting organizational behavior (Coyle-Shapiro $\&$ Kessler, 2000). Psychological contract fulfillment was shown to result in a number of positive outcomes. For example, employees who perceive that their employer has kept their promises report higher job satisfaction, stronger commitment to the organization, and perform better on their jobs (Coyle-Shapiro \& Parzefall, 2008).

However, very often employers are not able to fulfill the obligations they have promised, leading employees to experience psychological contract breach (PCB). In their seminal paper, Robinson and Rousseau (1994) showed that PCB is more the norm than the exception, and, when it happens, can lead to undermined trust between employee and employer, dissatisfaction among employees and even the dissolution of the relationship. Consistent with that, it has been shown that that PCB is negatively related to job satisfaction (Raja, Johns \& Ntalianis, 2004), intention to stay in the organization (Turnley \& Feldman, 2000), job performance (Johnson \& O'Leary-Kelly, 2003), trust in the organization (Zhao et al., 2007), organizational citizen behaviors (Restubog, Bordia \& Tang, 2007) and organizational commitment (Zhao et al., 2007). At the same time, PCB was shown to be positively correlated with counterproductive work behaviors (Bordia, Restubog \& Tang, 2008), absenteeism and organizational cynicisms (Johnson \& O'Leary-Kelly, 2003).

Since the research evidence about consequences of PCB is mostly based on the samples from well-developed market economies (Zhao et al. 2007), we wanted to expand this evidence by investigating the effects of PCB in a heterogeneous sample of Croatian employees. 
In our study we wanted to answer three main research questions:

(1) Is PCB experienced among Croatian employees and how does it depend on their characteristics?

(2) Does PCB result in unfavorable job attitudes and lower job performance?

(3) Are the effects of PCB on job attitudes/performance stronger in certain groups of employees?

As main employee characteristics that could be related to $\mathrm{PCB}$, we selected gender, age, tenure with current employer and employment sector (public vs. private sector). In order to understand the consequences of PCB we measured job satisfaction and organizational commitment as the most salient job attitudes (Jex \& Britt, 2014), and three main aspects of job performance (Robbins \& Judge, 2012): in-role performance, organizational citizenship behaviors (OCBs), and counterproductive work behaviors (CWBs). While in-role performance refers to the formal job requirements, main tasks and duties employees have to perform and are paid for, OCBs are behaviors that go beyond the core job requirements and support organizational environment (e.g., altruism towards coworkers). Finally, CWBs include acts that are counterproductive to the organizational goals, such as acts of production and interpersonal deviance.

\section{Method}

\section{Participants}

The sample consisted of 363 employees from various Croatian companies. They were recruited by psychology students, with following inclusion criteria: working for minimum a year in the same company, at least 20 hours a week, having at least two coworkers, and not being on the highest position in the company. $42.3 \%$ of employees worked in the private sector while $57.6 \%$ of participants worked in the public sector or state-owned companies. They were heterogeneous regarding their demographics, with average age $38.1(\mathrm{SD}=11.66)$ and $50.4 \%$ female participants. $47.1 \%$ participants had maximum high-school diploma, whereas others had college or university degree. On average, participants had $14.7(\mathrm{SD}=11.38$ ) years of service, including average $10.3(\mathrm{SD}=10.01)$ years in the same company.

\section{Instruments}

Psychological Contract Breach

A 5-item measure developed by Robinson and Morrison (2000) was used to assess perceived psychological contract breach. It captured employee's perceptions of how 
well their organization has fulfilled their obligations to them. Sample items for this scale are „My employer has broken many of its promises to me even though I've upheld my side of the deal." and "So far my employer has done an excellent job of fulfilling its promises to me." (Reversely coded item). Participants gave their responses on a five-point scale where $1=$ strongly disagree and $5=$ strongly agree. Cronbach's alpha of this scale in our study was .89 .

\section{Job Satisfaction}

The well-known Brayfield and Rothe's (1951) 5-item scale was used to measure job satisfaction. Example item is "Most days, I am enthusiastic about my job." Participants responded on the scale ranging from $1=$ strongly disagree to $5=$ strongly agree. The scale demonstrated an internal consistency reliability of .86.

\section{Organizational Commitment}

To assess organizational commitment, we used Colquitt's (2001) 3-item measure. Responses were given on the 5 -point scale anchored by $1=$ strongly disagree and 5 = strongly agree (e.g. "I feel a sense of belonging to this organization."). The scale's Alpha reliability in this study was .84 .

\section{In-role Performance}

A 7-item measure developed by Williams and Anderson (1991) was used to measure in-role performance - behaviors that are recognized by formal reward systems and are part of the requirements as described in job descriptions. Participants responded on the scale ranging from $1=$ completely false to $5=$ completely true, indicating how they behaved on their job during the last year (e.g. "Adequately completed assigned duties.”). The scale's Cronbach's alpha in this study was .82.

\section{Organizational Citizenship Behavior}

We used the Organizational Citizenship Behavior Checklist (OCB-C; Fox et al., 2011) consisting of 20 items describing various organizational citizenship behaviors. On the 5 -point scale anchored by $1=$ never and $5=$ every day, respondents' task was to rate how often in the last year they performed extra role behaviors on their jobs (e.g. "Volunteered for extra work assignments."). The total score scale demonstrated an internal consistency reliability of .89 . 


\section{Counterproductive Work Behavior}

We administered the Counterproductive Work Behavior Checklist (CWB-C; Spector et al., 2006) consisting of 33 items. The scale assesses employee intentional behaviors that harm the organization and people in the organization. Participants rated how often in the last year they behaved as described by the item, using the response scale ranging from $1=$ never to $5=$ every day (e.g. "Taken a longer break than you were allowed to take”). In this study, the total score scale's Alpha reliability was .91.

\section{Demographic Questionnaire}

The participants were asked about their gender, age, educational degree, years of service and some other features of their work and company.

All instruments were administered in Croatian, after we translated them from English using the translation-back translation procedure.

\section{Procedure}

Participation in the study was voluntary and anonymous. The participants were tested individually by psychology students. They first filled-in questionnaires asking about their attitudes toward the organization (including PCB), then the job performance measures, and finally the demographic questionnaire. Since this study was a part of a larger data collection, the participants filled-in some additional questionnaires that will not be reported in this paper. The participants returned questionnaires via psychology student in a sealed envelope in order to preserve their anonymity.

\section{Results and Discussion}

\section{Descriptive Statistics}

Descriptive statistics of the main study variables are shown in Table 1.

Descriptive statistics suggest that significant variability exists on all study variables. Average psychological contract breach was 2.50 and the total range covered the values that reflect complete contract fulfillment (1) and maximum contract breach (5). Average values for job satisfaction and organizational commitment were in positive part of the response scale, suggesting on average favorable attitudes towards the job and the organization. The job performance self-reports suggest that the average participant claimed to fulfill his/her main job tasks, but was also ready to admit deviant behavior at work (i.e., CWBs) and relatively low extra-role engagement (i.e., OCB). 
Table 1: Descriptive statistics of main study variables $(\mathrm{N}=363)$

\begin{tabular}{|l|c|c|c|c|}
\hline \multicolumn{1}{|c|}{ Variable } & M & SD & Min & Max \\
\hline Psychological contract breach & 2.50 & 0.92 & 1.00 & 5.00 \\
\hline Job attitudes & & & & \\
\hline Job satisfaction & 3.68 & 0.80 & 1.00 & 5.00 \\
\hline Organizational commitment & 3.24 & 1.02 & 1.00 & 5.00 \\
\hline Job performance & & & & \\
\hline In-role performance & 4.44 & 0.48 & 2.43 & 5.00 \\
\hline Organizational citizenship behavior & 3.09 & 0.70 & 1.40 & 4.90 \\
\hline Counterproductive work behavior & 1.21 & 0.25 & 1.00 & 4.19 \\
\hline
\end{tabular}

Note: $\mathrm{M}$ - mean; SD - standard deviation; Min - minimal score; Max - maximal score

\section{Psychological Contract Breach and Employees' Demographic Characteristics}

In Table 2, the correlations between PCB and employees' demographic characteristics are shown.

Table 2: Correlations of psychological contract breach with employees' demographic characteristics $(\mathrm{N}=363)$

\begin{tabular}{|l|c|}
\hline & r \\
\hline Gender & \\
\hline Age &,- 02 \\
\hline Tenure with current employer &, $23^{*}$ \\
\hline Education $^{2}$ &, $29^{* *}$ \\
\hline Sector $^{3}$ &,$- 11^{*}$ \\
\hline
\end{tabular}

Note: $\mathrm{r}=$ Pearson $\mathrm{r}$ correlation coefficient. $11=$ male, $2=$ female; $21=$ high school education or lower, $2=$ college degree or higher; $31=$ private sector; $2=$ public sector.

Significant correlations between PCB and employees' demographic characteristics were observed for four out of the five employees' demographic characteristics. Stronger PCB was reported by older employees, those that are longer employed by current employer, lower educated and employed in public sector. These results can probably be explained by adversities experienced on Croatian labor market during the last several years. The recession that started in 2008 has strongly hit most of Croatian companies and forced them to cut personnel costs (Franičević, 2011). Stronger PCB perceptions among older and longer tenured employees might be caused by their perceptions that they delivered their side of bargain but were at the same time disappointed by the returns they received from the company. Macroeconomic circumstances could also explain the correlations of PCB with education and sector variables. Earlier research showed that the economic downturn most hardly hit 
unskilled and lower educated workers on Croatian labor market (Galić \& Plećaš, 2012). Though somewhat surprising, higher PCB in public sector could probably be explained by the fact that, even thought the economy seemed to be out of recession at the time the data collection took place (Croatian Bureau of Statistics, 2016), because of large state-budget deficit, austerity measures in the public sector are still widely enforced. However, it must be stressed that all these correlations are small in size (Cohen, 2013), and the explanations we offered are speculative and warrant further research.

\section{Relationship of Psychological Contract Breach with Job Attitudes and Job Performance}

In Table 3 we showed correlations of PCB with the job attitudes and the job performance variables we have observed in our study and compared them with the results reported in recent meta-analysis of PCB correlates by Zhao et al. (2007).

Table 3: Correlations of psychological contract breach with job attitudes and job performance $(\mathrm{N}=363)$

\begin{tabular}{|l|c|c|}
\hline \multicolumn{1}{|c|}{ Outcome variable } & \multicolumn{2}{c|}{ r } \\
\hline Job attitudes & Our study & Zhao et al. (2007) \\
\hline Job satisfaction & & \\
\hline Organizational commitment &,$- 49 * *$ &,- 54 \\
\hline Job performance &,$- 35^{* *}$ &,- 38 \\
\hline In-role performance & & \\
\hline Organizational citizenship behavior &,$- 18^{* *}$ &,- 24 \\
\hline Counterproductive work behavior &, 07 &,- 14 \\
\hline
\end{tabular}

Note: $r=$ Pearson $r$ correlation coefficient. 1Zhao et al (2007) did not cover CWBs in their meta-analysis

As might be seen from Table 3, PCB correlates significantly with both job attitudes - employees that perceived stronger PCB reported lower job satisfaction and weaker organizational commitment. Regarding job performance variables, PCB correlates negatively with in-role performance and positively with CWBs. This suggests that PCB manifests in less effort invested in one's core job tasks and in more undesirable behavior, counterproductive to the organizational goals. The effect sizes of observed relationships are moderate to strong in the case of job attitudes but relatively small for the job performance variables (Cohen, 1988). Still, as can be seen from Table 3, all those values are highly comparable to those reported in the meta-analysis on the impact of PCB on work-related outcomes (Zhao et al., 2007). This suggests that the detrimental effect of PCB on job attitudes and job performance is similar among 
Croatian employees as the one observed among employees working in more developed economies. Irrespective whether you work on a labor market characterized with many job opportunities (as in well-developed countries), or the ones with scarce job vacancies (as in Croatia), PCB "hurts" the same.

\section{Moderating Effect of Employees' Characteristics On the Relationship of} Psychological Contract Breach with Job Attitudes and Job Performance

In order to better understand the effects of PCB, we tested if the effects of PCB on job attitudes and job performance were stronger for some groups of employees. Therefore, we performed a series of moderated regression analyses (Hayes, 2013) where we tested the interactions between PCB and participants' characteristics in explaining job attitudes/job performance. All analyses followed the same format:

Figure 1: Significant interactions between psychological contract breach (PCB) and employees`demographic characteristics in explaining job attitudes.

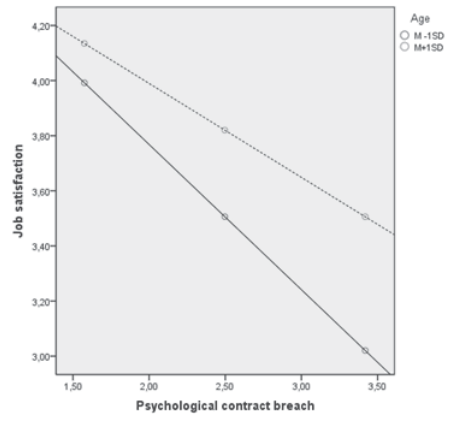

(a) Job Satisfaction: PCB $\times$ Age

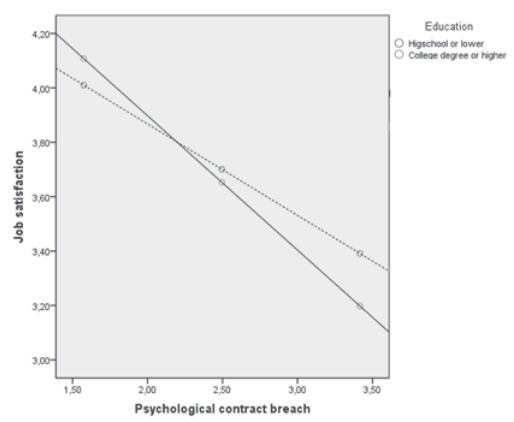

(c) Job Satisfaction: PCB x Education

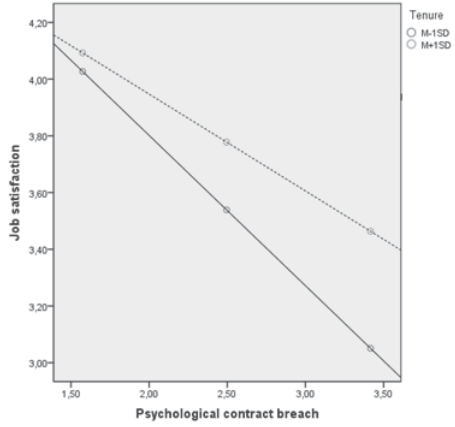

(b) Job Satisfaction: PCB x Tenure

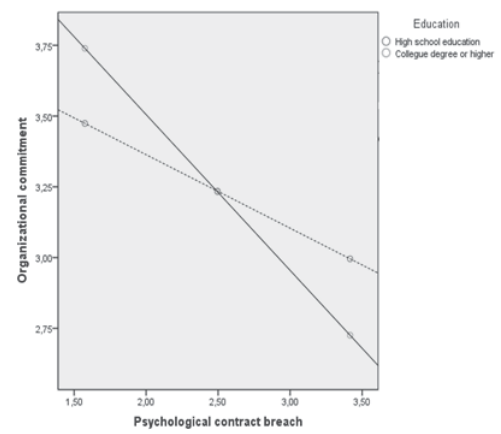

(b) Commitment: PCB x Education 
in the first step of a hierarchical regression analysis we included predictors (i.e., the PCB score and a demographic variable), and in the second step the interaction computed as the product between the two predictor variables. Interactions below the .05 significance level were considered to be statistically significant.

Among all calculated analyses, four interaction terms were found to be statistically significant. Three were related to job satisfaction: the interactions between age and PCB, tenure and PCB, and education and PCB. The fourth was the interaction between education and PCB in explaining organizational commitment. Significant interactions are shown in

As might be seen from the figure, PCB effect on job satisfaction depends on some employees' demographic characteristics. PCB leads to stronger job dissatisfaction among younger and better educated participants, with shorter tenure in the organization. Significant interaction between PCB and education is also observed for organizational commitment: the negative effect of PCB on organizational commitment is more pronounced in a group of better educated employees. Perhaps employment situation is more central for an individual's identity among better educated, shorter tenured and younger employees, and, therefore, PCB among them leads to stronger reactions that manifest in less favorable job attitudes.

\section{Limitations and Future Research}

Our study has several characteristics that limit conclusions and point to future research directions. First, our study was cross-sectional with all variables measured in one-time point. Though our interpretations imply causality from PCB towards job attitudes and job performance, the direction might go other way round. Future research should use longitudinal research designs in order to discern actual causality sequence. Second, all our variables were measured with self-report data, so the relationships could be inflated because of the common-method bias (Podsakoff et al., 2003). Future studies should use other sources at least for some of the variables (e.g., peer/supervisor ratings of in-role performance/OCB/CWBs). Finally, our conclusions are based on a sample of convenience. Though that sample is relatively heterogeneous and large in size, additional studies using other samples of Croatian employees are certainly needed to better understand occurrence of PCB and its consequences.

\section{Managerial Implications}

Our results confirm that PCB has important negative consequences both for employee and employing organization and, therefore, should be managed. The best way of PCB management is its prevention during the process of psychological contract 
formation. Psychological contract is based on the promises employees receive during recruitment and/or early organizational socialization from managers and human resources specialists. During those phases it is important to clearly communicate mutual expectations, and to avoid unrealistic promises that could create future PCB. However, even if organizational agents were completely honest and realistic, certain extent of unfulfilled promises might result from the circumstances that happen to the organization (e.g., recession, mergers and acquisitions). In that case, the organizational agents (i.e., managers) should give a detailed explanation for broken promises, and, show that they were not intentional. Thorough and honest explanations might alleviate experienced PCB and prevent its negative effect on job attitudes and organizational behavior.

\section{Conclusion}

In a troubled economy seeking its position in the EU market, it is expected that many employers will not be able to deliver the promises they implicitly or explicitly gave to their employees when they were joining the organization. Our results suggest that unfulfilled promises reflect in lower attitudes about one's job and organization. This might especially be the case with employees that represent company's most valuable human resources (i.e., young and highly educated newcomers). Even more important, PCB also reflects in lower "core" job performance and more CWBs, creating clear economic costs to the employing organization. All this makes PCB an important issue managers and human resources specialists must approach with the utmost seriousness.

\section{REFERENCES}

Bordia, P., Restubog, S.L.D. \& Tang, R.L. (2008). When employees strike back: investigating mediating mechanisms between psychological contract breach and workplace deviance. Journal of Applied Psychology. 93(5), 1104-1117. DOI: 10.1037/0021-9010.93.5.1104.

Brayfield, A.H. \& Rothe, H.F. (1951). An index of job satisfaction. Journal of Applied Psychology. 35(5), 307-311. DOI: 10.1037/h0055617.

Cohen, J. (2013). Statistical power analysis for the behavioral sciences. New York: Academic Press.

Colquitt, J.A. (2001). On the dimensionality of organizational justice: a construct validation of a measure. Journal of Applied Psychology. 86(3), 386-400. DOI: 10.1037//0021-9010.86.3.386.

Coyle-Shapiro, J.A. \& Kessler, I. (2000). Consequences of the psychological contract for the employment relationship: A large scale survey. Journal of Management Studies. 37(7), 903-930. DOI: 10.1111/1467-6486.00210.

Coyle-Shapiro, J. A. \& Parzefall, M. (2008). Psychological contracts. In C. L. Cooper \& J. Barling (Eds.), The SAGE handbook of organizational behavior (pp. 17-34). London, England: SAGE.

Croatian Burreau of Statistics. (2015). Key figures. Retrieved January 26 2016, from http://www.dzs. hr/default_e.htm. 
Cropanzano, R. \& Mitchell, M.S. (2005). Social exchange theory: An interdisciplinary review. Journal of Management. 31(6), 874-900. DOI: 10.1177/0149206305279602.

Franičević, V. (2011). Croatia: Prolonged crisis with an uncertain ending. In D. Vaughan-Whitehead (Ed.), Work Inequalities in the Crisis: Evidence from Europe (pp. 143-197). UK: Edward Elgar and International Labour Office. DOI: 10.4337/9780857937513.00011.

Galić, Z. \& Plećaš, M. (2012). Quality of working life during the recession: The case of Croatia. Croatian Economic Survey, 14, 5-41.

Gouldner, A.W. (1960). The norm of reciprocity: A preliminary statement. American Sociological Review. 25(2), 161-178. DOI: 10.2307/2092623.

Fox, S., Spector, P. E., Goh, A., Bruursema, K. \& Kessler, S. R. (2012). The deviant citizen: Measuring potential positive relations between counterproductive work behaviour and organizational citizenship behaviour. Journal of Occupational and Organizational Psychology. 85(1), 199220. DOI: 10.1111/j.2044-8325.2011.02032.x.

Hayes, A.F. (2013). Introduction to mediation, moderation, and conditional process analysis: A regression-based approach. Guilford Press.

Jex, S.M. \& Britt, T.W. (2014). Organizational psychology: A scientist-practitioner approach. John Wiley \& Sons.

Johnson, J.L. \& O'Leary-Kelly, A.M. (2003). The effects of psychological contract breach and organizational cynicism: Not all social exchange violations are created equal. Journal of Organizational Behavior. 24(5), 627-647. DOI: 10.1002/job.207.

Levinson, H. (1965). Reciprocation: The relationship between man and organization. Administrative Science Quarterly. 9(4), 370-390. DOI: 10.2307/2391032.

Podsakoff, P.M., MacKenzie, S.B., Lee, J.Y. \& Podsakoff, N.P. (2003). Common method biases in behavioral research: a critical review of the literature and recommended remedies. Journal of Applied Psychology. 88(5), 879-903. DOI: 10.1037/0021-9010.88.5.879.

Raja, U., Johns, G. \& Ntalianis, F. (2004). The impact of personality on psychological contracts. Academy of Management Journal. 47(3), 350-367. DOI: 10.2307/20159586.

Restubog, S.L.D., Bordia, P. \& Tang, R.L. (2007). Behavioral Outcomes of Psychological Contract Breach in a Non-Western Culture: The Moderating Role of Equity Sensitivity. British Journal of Management, 18(4), 376-386. DOI: 10.1111/j.1467-8551.2007.00531.x.

Robbins, S.P. \& Judge, T.A. (2012). Organizational Behavior (15th Ed.). Prentice Hall.

Robinson, S. L. \& Morrison, E. W. (2000). The development of psychological contract breach and violation: A longitudinal study. Journal of Organizational Behavior. 21(5), 525-546. DOI: 10.1002/1099-1379(200008)21:5<525::AID-JOB40>3.0.CO;2-T.

Robinson, S.L. \& Rousseau, D.M. (1994). Violating the psychological contract: Not the exception but the norm. Journal of Organizational Behavior. 15(3), 245-259. DOI: 10.1002/job.4030150306.

Rousseau, D.M. (1990). New hire perceptions of their own and their employer's obligations: A study of psychological contracts. Journal of Organizational Behavior. 11(5), 389-400. DOI: 10.1002/ job.4030110506.

Rousseau, D.M. \& McLean Parks, J. (1993). The contracts of individuals and organizations. Research in Organizational Behavior. 15, 1-43.

Spector, P.E., Fox, S., Penney, L.M., Bruursema, K., Goh, A. \& Kessler, S. (2006). The dimensionality of counterproductivity: Are all counterproductive behaviors created equal?. Journal of Vocational Behavior. 68(3), 446-460. DOI: 10.1016/j.jvb.2005.10.005.

Turnley, W. H. \& Feldman, D. C. (2000). Re-examining the effects of psychological contract violations: unmet expectations and job dissatisfaction as mediators. Journal of organizational behavior, 21(1), 25-42. DOI: 10.1002/(sici)1099-1379(200002)21:1<25::aid-job2>3.0.co;2-z.

Zhao, H.A.O., Wayne, S.J., Glibkowski, B.C. \& Bravo, J. (2007). The impact of psychological contract breach on work-related outcomes: A meta-analysis. Personnel Psychology, 60(3), 647-680. DOI: 10.1111/j.1744-6570.2007.00087.x. 
